\title{
Comparative Legal Research : Consumer Legal Term In The Article 1 Number 2, Law No. 8, 1999 - Indonesia VS. Chapter I Article 2, Law No. 8078 - Brazil
}

\author{
Junita Kaseme Tan ${ }^{1}$, Dennis Darmawan $\mathrm{Jo}^{2}$, Arni Winarsih, Kiki Kusumawati and Yongki \\ Sidharta Gunawan ${ }^{3 *}$ \\ ${ }^{1}$ Master of Law, Pelita Harapan University, Surabaya, Indonesia \\ ${ }^{2}$ Master of Law, Airlangga University, Surabaya, Indonesia \\ ${ }^{3}$ Master of Notary, Airlangga University, Surabaya, Indonesia
}

\begin{abstract}
The growth of the international-trades volume has increased, and the developed countries hope to sell their products to developing countries that have a bigger market potential because of their large populations. With the existence of quite big market potential in the world trade, developing countries such as Indonesia and Brazil must have a legislation that can give a protection for their citizens as the consumers of goods or services in the developed countries. Based on that issue, this research implements an analysis of the consumer's legal term stated in the Article 1 number 2 of the Law No 8, 1999 (Consumer Protection Act - Indonesia) and Chapter I Article 2, Law No. 8078 of September $11^{\text {th }}, 1990$ (Code of Consumer Defense and Protection-Brazil). This law research will use the method of juridical normative, with the comparative approach of legislation.
\end{abstract}

\section{Introduction}

Globalization is an integration process occurred as the result of interchanging global perspective, products, ideas, and other cultural aspects across world-time and worldspace [1]. Globalization encourages countries in the world to carry out international integration process that significantly improves global trade because one of the effects of globalization is the implementation of WTO free market in 2020. By the implementation, there will be no trade limitations such as tariff, quota, and any other forms of trade limitation. Developing countries with high population becomes a potential market for developed countries to trade their products and services. Based on the data statistic, Indonesia and Brazil meet the criterion of developing countries with high population that becomes the destinations of other countries.

Indonesia, with potential population of $224,138,438$ (2000) is the fourth most populated country in the world, while Brazil is a developing country which is the fifth most populated country in the world with potential population of 175,552,771 (2000) [2]. Based on the

\footnotetext{
* Corresponding author: sidhartayongki@gmail.com
} 
statistical data obtained from the publication of Central Intelligence Agency concerning market potentiality of Indonesia and Brazil in terms of trade and consumption, Indonesia's household consumption rate is $57.5 \%$ with export of products and services rate $19.2 \%$ and import of products and services rate $18.4 \%$ [3]. Meanwhile, Brazil's household consumption rate is $63.5 \%$ with export of products and services rate $11.8 \%$ and import of products and service rate $-11.7 \%$ [4]. The data indicates market segmentation potentiality of these two countries. The great potentiality surely must be followed up by providing legal protection towards its citizens as potential world market segmentation. The implementation of legal protection of each country is by stipulating laws concerning the issue, for example, the implementation of legal protection by Indonesian government by enacting Law Number 8 concerning Consumer Protection. Brazilian government also enacts a similar regulation, named Law No. 8078 of September 11, 1990 Code of Consumer Defense and Protection.

It is very interesting to compare the Consumer Protection Act stipulated by the two countries adopting civil law system, namely Indonesia [5] and Brazil [6]. Therefore, based on the background explained above, the legal issue which is going to be discussed in this study is the comparison of legal terms concerning consumer stated on Article 1 number 2 Law Number 8 Year 1999 - Consumer Protection Act Indonesia (Indonesian CPA) and Chapter I Art. 2, Law No. 8078 of September 11, 1990 - Code of Consumer Defense and Protection - Brazil (CCD Brazil).

\section{Objective of the study}

The research objective is to analyze the comparison of consumer legal term stated on Indonesian CPA and CCD - Brazil.

\section{Methodology}

The method to be used in this study is comparative legal studies. This study applies to analyze and define legal issues focusing on similarities and differences of laws [7].

\section{Discussion}

\subsection{Different Definition of Consumer Legal Term}

The legal term of consumer stated on Article 1 number 2 of Indonesian Consumer Protection Act is a person, without specifically mentioning whether the person here refers to a physical person or a corporate as stated on consumer legal term of Chapter I Art.2, Law No.8078 of September 11, 1990 (CCD Brazil).

The legal term of consumer stated on Article 1 number 2 of Indonesian CPA defines consumer as any person who uses while Chapter I Art.2 CCD Brazil provides definition "... any person or corporate entity who acquires or uses..". The phrase "any person who uses" stated on Article 1 number 2 implies the definition that a consumer is any person who uses or utilizes [8]. This definition is in line with the explanation of Article 1 number 2 of Indonesian CPA as follows:

Economics literature acknowledges the terms of final consumer and intermediate consumer. Final consumer is the final user of a product while intermediate consumer is a person who uses a product as part of certain production process. The definition of consumer here refers to final consumer. 
A consumer does not have to provide their achievement by paying money to obtain goods and/or services. In other words, the relationship between consumer and business actor is not necessarily contractual (the privity of contract). Hence, the definition of consumer stated on legal term of Article 1 number 2 refers to the final consumer (a person who utilizes the goods or services) while the intermediate consumer cannot be categorized as the consumer meant in Indonesian CPA. The Act does not specify different definitions of the terms "to be worn, to be used, and to be utilized" [9].

The words "acquires or uses" stated in Chapter I Art.2 of CCD Brazil implies the definition of a consumer as a person or corporate entity who receives or utilizes products or services. Furthermore Chapter I Art. 2 stated that a consumer who intervenes in consumer relationship may be categorized as intermediate consumer whereas Chapter I Art. 2 explicitly classifies consumer as a final user. Regarding this contradiction, Jose Geraldo Brito [10] stated: In the single paragraph of the same Article., the CCD asserts that "a group of people, although indeterminable, who have intervened in consumption relationships is similar to a consumer". According to José Geraldo Brito Filomeno, what this paragraph is aiming at is the universality, the totality of product and service consumers, a class or category once related to a product or service.

From this argument, it is stated that a group intervening consumer relationship is similar to a consumer, therefore what stated on Chapter I Art. 2 of Law No.8078 of September 1990 (CCD Brazil) contradicts its explanation concerning the extension of consumer definition as collective individuals who may be participating in consumer relationships. The definition of final consumer should be a person who uses goods/services for their personal uses/noncommercial purposes (end user, final consumer, consumer of the consumer market) [11]. There is no participation in consumer relationship because the final consumer is the final person who consumes the product or service.

The consumer legal term Indonesian CPA is more specific in defining goods and/or services available in the society to be consumed for personal use, family, other people and other living creatures, and not for commercial purposes. The statement "available to the society" implies that the goods or services must be widely offered to the society and accessible by many people. In this sense, any special (closed) and individual-oriented services are excluded from this definition [12]. The goods and/or services offered to the society must be available in the society. This provision correlates with the statement on Article 9 Paragraph (1) number e of Indonesian CPA: "the goods and/or services are available;" However, in today's more complex commerce, this requirement is no longer demanded by consumer society, for example it is very common for a house developer to carry out transaction before the house built. Even in certain types of transaction, such as futures trading the existence of the goods being traded is not a priority [13]. The element added in this definition also attempts to extend the scope of benefits. The benefit here is not limited merely on personal and family uses [13]. It also includes other people's benefits in addition to personal and family uses. Meanwhile, Chapter I Art. 2, CCD Brazil does not provide specific explanation on goods/services available in the society. CCD Brazil emphasizes that only goods or services acquired or used as final user can be categorized as consumer. Therefore, although it does not explicitly state goods or services that are available in the society, Chapter I Art. 2, CCD Brazil still includes a person in consumer legal term as long as they acquire or use the goods or services in wide scale.

The statement "not for commercial purposes" in Article 1 number 2 consumer legal term aims to emphasize the explanation of the article that a consumer meant by the article refers to final consumer, not intermediate consumer. The characteristics of the consumer indicate 
that he/she does not always provide his/her achievement by paying some money to acquire goods and/or services. In other words, the principle of legal relationship between a consumer and a business actor is not necessarily contractual (the privity of contract) [13]. This principle correlates with the way a consumer acquires a product, namely [14]:

1. Purchasing. For a person who acquires a product through purchasing, he/she must be involved in a contract with the actor. A consumer gains legal protection from this contract.

2. Other ways of acquiring, namely presents, gifts, and inheritance/legacy. In this type of acquiring, a consumer is not involved in contractual relationship with the actor thus the consumer does not have legal protection provided by the contract. The required legal protection is provided by the state in the form of regulations aimed to protect the consumer(s), in this case Consumer Protection Act.

Chapter I Art.2 CCD Brazil does not specify whether the acquired or used products/services are traded or not. However, the statement is more concise and clearer than Indonesian CPA. Chapter I Art. 2 CCD Brazil directly addresses consumer as final consumer as stated on Geraldo Brito Filomeno's opinion: “...the consumer concept adopted by the Code had an exclusively economic connotation. In other words, it took into account only the acquisition of goods and services rendered for a final addressee, presuming that those acts are for a personal need and not for the development of another business activity" [15]. According to this opinion, the concept of consumer poses exclusive connotation in which the purpose of all actions made by a final consumer is considered as personal need, and not as business development.

\subsection{Consumer as a Legal Subject}

The definition of legal subject proposed by Jack M. Balkin is only limited on individuals who understand something thus that something serves as the object of their understanding. Consumer legal term stated on CCD Brazil explicitly defines consumer as every physical person or corporate entity who acquires or uses a product or service as a final user. However, the consumer legal term of Indonesian CPA does not specifically explain who the consumer referred to in this law is, whether the consumer here refers to physical person (natuurlijk persoon) or legal entity (rechtpersoon). Does the definition of consumer in Indonesian CPA also refer to legal entities (rechtpersoon)? This topic is debatable because the explanation of Article 1 number 2 does not specify whom the consumer stated in this Article referred to. Therefore, the definition of person in consumer legal term of Indonesian CPA needs to be evaluated based on law theories and law concept of person existing in Indonesian positive law.

Persoon (person) refers to legal subject, the holder of right and obligation. The holder of right and obligation may be human being or legal entities [16]:

Legal entity (rechtspersoon) are institutions or organizations. Legal entity (recht persoon) is a person created by law. Rechtpersoon is commonly known as persona ficta a person created by law as persona [17]. Therefore, the word "person" stated on Article 1 number 2 of Indonesian CPA may also refer to legal entities.

Meanwhile, the definition of person as natuurlijk persoon refers to living human beings starting from the day he/she was born until the day he/she dies. Even in civil law, there is statement nasciturus pro iam nato habetur [18]. This statement was found on Article 2 BW means every child in a mother's womb is considered to have been born whenever the child's interest requires. If the child dies during deliverance, he/she is considered never existed. 
Hence, the legal subject stated on Article 1 number 2 Indonesian CPA refers to all living human beings, starting from a fetus in mother's womb until a person dies.

Compared to consumer legal term stated on Article 1 number 2 of Indonesian CPA, Chapter I Art. 2 of CCD Brazil seems to be better in defining a consumer as a physical person or as a corporate (legal entity) so that there is no multiple interpretation concerning the definition of consumer. Similar to Indonesia, Brazilian law system also acknowledges rechtpersoon although it is called in different name. Several Brazilian laws used legal entity and juridical person which is different from person, for example in Civil Code Chapter II Art.15 states "Juridical persons of public law are civilly responsible for acts of their representatives who in that capacity cause damages to third persons, by proceeding in a manner contrary to law or failing in a duty prescribed by law, saving their right over against the causers of the damage". Brazilian Antitrust Laws No, 8884 of June $6^{\text {th }} 1994$ classifies legal entity into two categories, namely private and public. Brazilian Civil Code (Law 10406/02), or Brazilian Corporate Law (Law No. 6.404, of December 15, 1976) also categorizes legal entity into two, namely The Limited Liability Companies ("Limitadas" or "Ltda.") and Limited Liability Corporation (S/A).

In the consumer legal term stated on Chapter I Art. 2, CCD Brazil correlates with Civil Code Brazil Book I. Hence, a consumer refers to physical person described in Civil Code Brazil Book I, referring to all people, either he/she is Brazilian nationality, expatriate, or even unborn babies. All of them has equal rights in Brazilian law. Related to consumer stated on Chapter I Art. 2 CCD Brazil, the definition of consumer in Brazilian Consumer Protection Act classified fetus inside mother's womb as a consumer that needs to be protected [19]. As stated on Art. 17 of CCD Brazil: "For the purposes of this Section, all victims of events shall be considered consumers". The extension of physical person is because the similarity between Brazil and Indonesia, they both adopt civil law with expression nasciturus pro iam nato habetur [20].

\section{Conclusion}

From these two Consumer Protection Acts, there are some differences and similarities. The results of comparing consumer legal term stated on Article 1 number 2 of Indonesian CPA and Chapter I Art. 2, CCD Brazil can be concluded as:

1. The definition of consumer stated on these two acts has its own unique characteristics. In Article 1 number 2 of Indonesian CPA, the definition has been extended to natuurlijk persoon and rechtpersoon while Chapter I Art 2 of CCD Brazil has explicitly defines consumer as physical person or corporate entity.

2. Consumer protection in these two Acts targets consumer as final user. However, Chapter I Art.2, CCD Brazil poses contradiction concerning the definition of final user because of the word acquires stated on this Act. Besides the definition of consumer who participates in consumer relationship which may refer to intermediate consumer stated on sole paragraph of CCD Brazil. On otherhand, the explanation of Article 1 number 2 of Indonesian CPA clearly stated that the legal subject of the law is final user, intermediate user does not include as legal subject of consumer protection.

\section{References}

1. G. Mark D., I. Alexey, Applied Natural Science Environmental Issues and Global Perspectives (Apple Academic Press, New Jersey, 2016).

2. G. Geoffrey, World Population 2nd (ABC-CLIO, Santa Barbara, 2005). 
3. Central Intelligence Agency, The World Factbook, Accessed at: https://www.cia.gov/library/publications/the-world-factbook/geos/id.html. Accessed on March 29, $201810.56 \mathrm{pm}$.

4. Central Intelligence Agency, The World Factbook, Accessed at: https://www.cia.gov/library/publications/the-world-factbook/geos/br.html, Accessed on March 29, $201810.56 \mathrm{pm}$.

5. A. Romli, W. Kodrat, Analisis Ekonomi Mikro tentang Hukum Pidana Indonesia, (Kencana, Jakarta, 2016).

6. C. David, The BRIC States and Outward Foreign Direct Investment, (Oxford University Press, Oxford, 2013).

7. B. Ishwatra, Comparative Method of Legal Research: Nature, Process and Potentiality, Journal of The Indian Law Institute 57, 2, (2015).

8. Badan Pengembangan dan Pembinaan Bahasa, Kemetrian Pendidikan dan Kebudayaan, Accessed at: https://kbbi.web.id/pakai, Accessed on April 14, 2018.

9. K. C. T. Siwi, Hukum Perlindungan Konsumen (Sinar Grafika, Jakarta, 2008).

10. Pinto L. R. Maia, Consumer Protection in Brazil General Review, (School of Business and Public Management, The George Washington University, Washington, 2002).

11. Anonim, Hukum Perlindungan Konsumen, (Maranatha University, 2010).

12. M. Ahmadi and S. Yodo, Hukum Perlindungan Konsumen (PT. Raja Grafindo Persada, Jakarta, 2007).

13. G. Shidarta, Hukum Perlindungan Konsumen (PT Grasindo, Jakarta, 2006).

14. Rosmawati, Pokok-Pokok Hukum Perlindungan Konsumen (Prenadamedina Group, Depok, 2018).

15. P. L. R. Maia, Consumer Protection in Brazil General Review, (School of Business and Public Management, The George Washington University, Washington, 2002).

16. S. Dedi, Aspek Hukum Wewenang dan Tagung Jawab, Jurnal Hukum dan Pembangunan 16, 2, (1986).

17. A. Chidir, Badan Hukum (Alumni, Bandung, 2005).

18. M. P. Mahmud, Pengantar Ilmu Hukum ( Kencana, Jakarta, 2017).

19. M. C. Lima, Consumer Law and Socioeconomic Development: National and International Dimensions (Springer, 2017).

20. M. P. Mahmud, Pengantar Ilmu Hukum ( Kencana, Jakarta, 2017). 